\title{
Irrigation farming - the guarantor of food safety of Ukraine in conditions of climate fluctuations
}

\author{
Vozhegova R. ${ }^{1}$, Kokovikhin S. ${ }^{2}$ \\ Institute of irrigation farming of NAAS, Nad-dnip-rianskyi, Kherson, 73483, Ukraine; e-mail: 1, 2izz.ua@ \\ ukr.net
}

The purpose. To systematize achievements of scientists-ameliorators of Ukraine, to analyze problems and prospects of researches. Methods. Analysis, synthesis, generalization. Results. The basic achievements of domestic scientists in branch of irrigation farming and amelioration in sphere of counteraction to adverse natural factors (global climate fluctuations, drought, deficiency of atmospheric rainfall), and also raise of productivity of crops and martempering quality of produce are brought. It is proved that for maintenance of the maximum productivity of irrigation in large equipments of cattlebreeding direction the greatest specific weight in crop rotations $(40-45 \%)$ should have grain and forage crops. In equipments which specialize on production of grain and industrial crops, during formation of crop rotations it is necessary to give absolute preference (at the level of $50-60 \%$ ) to cereal crops, including winter wheat $-20-25 \%$; corn $-20-25$, and also to industrial crops, mainly soya bean $-20-25 \%$. In equipments of vegetable direction specific weight of vegetable crops and potato should be increased up to $50-60 \%$ due to limitation of areas under grain and forage crops. At use of drip irrigation specific weight of vegetables and potato should be increased up to $80 \%$. From the point of view of adaptation of systems of farming agriculture on irrigated lands under conditions of global climate fluctuations researches on optimization of regimes of irrigation, development of disposition of sown area and crop rotations, systems of fertilizers, soil cultivations and protection of plants which are directed on intelligent use of naturalclimatic potential of steppe zone will be actual. Conclusions. Development of domestic scientists in branch of irrigation farming have great value for raising productivity and competitiveness of agrarian production of Ukraine and are directed on martempering economic efficiency and decrease of anthropogenic load upon agroecosystems.

Key words: irrigation, climate, drought, agricultural methods, crop rotations, regimes of irrigation, fertilizer, protection of plants, economic efficiency, environmental safety.

\section{https://doi.org/10.31073/agrovisnyk201811-04}

According to research results of meteorological scientists conducted on different continents of the Earth, it has been established that the climate of the planet is constantly changing under the influence of cosmic and anthropogenic factors both in the direction of cooling and warming [1]. Together with these factors, the global climatic conditions have a significant impact on human economic activity. Over the last 10 thousand years, the spread of agriculture has caused a sharp decline in forest areas, which also led to climate change and has a direct impact on agriculture, including on irrigation productivity [2].

It has been proved that climate change has occurred worldwide in recent years, which has a direct impact on agricultural productivity, including on irrigated agriculture. Given that global climatic conditions are volatile since the early 1980 s, the differentiation of meteorological parameters began to manifest more significantly both globally and at the level of individual local ecosystems. For example, over the past 25 years, the average daily air temperature in Ukraine has increased by about $1.5^{\circ} \mathrm{C}$, indicating a significant increase in the temperature regime and noticeable climatic changes. Especially such changes began to appear in the winter, in January and February, as the average temperature in these months increased by $2.3-2.5^{\circ} \mathrm{C}$. It should be noted that in July and August the temperature increase is $1.5-1.8{ }^{\circ} \mathrm{C}$, which is also a rather high indicator. During the transitional seasons, climate change is not so noticeable [3].

The simulation of climate change in the twenty-first century indicates that an increase in the emission of greenhouse gases into the atmosphere will increase the likelihood of droughts with abnormally low precipitation and an increase in surface temperature during the growing season. At the same time, in some regions of the world, the number of days with intense precipitation will increase. Possible growth of biological plants productivity due to increased concentration of carbon dioxide in the atmosphere. With global warming 
at $1{ }^{\circ} \mathrm{C}$, the zone of maximum productivity of vegetative cenoses in the northern hemisphere of the Earth will move to the north by $200-300 \mathrm{~km}[4]$.

The World Meteorological Organization unveils the results of analytical studies of global climate change assessments. Based on data provided by more than 10,000 experts from virtually all countries of the world, mathematical models of climate change scenarios have been constructed [5]. According to rigid forecasts, taking into account the warming rates that exist now, the average annual temperature in the northern hemisphere may increase by $5^{\circ} \mathrm{C}$ for 100 years (Fig. 1).

Taking into account the aforementioned trends and patterns, it can be argued that the climate in Ukraine is approaching dry subtropics. Beginning in the summer of 2012, almost all hot-climatic zones are observed in hot years with insufficient numbers or complete absence of atmospheric precipitation [6].

According to the National Central Geophysical Observatory, it has been established that over the past 20 years the temperature has continued to grow on the territory of Ukraine. For example, during this time the average annual temperature in Kiev increased by $2{ }^{\circ} \mathrm{C}$. The maximum warming occurs during the winter period, due to which the average temperature per year increases significantly.

It should be noted that the role of irrigation in the face of growing trends in global warming on Earth will be constantly rising [6-8]. In recent decades, under conditions of gradual warming of the climate, there is a steady trend towards a significant increase in the number of years with drought.

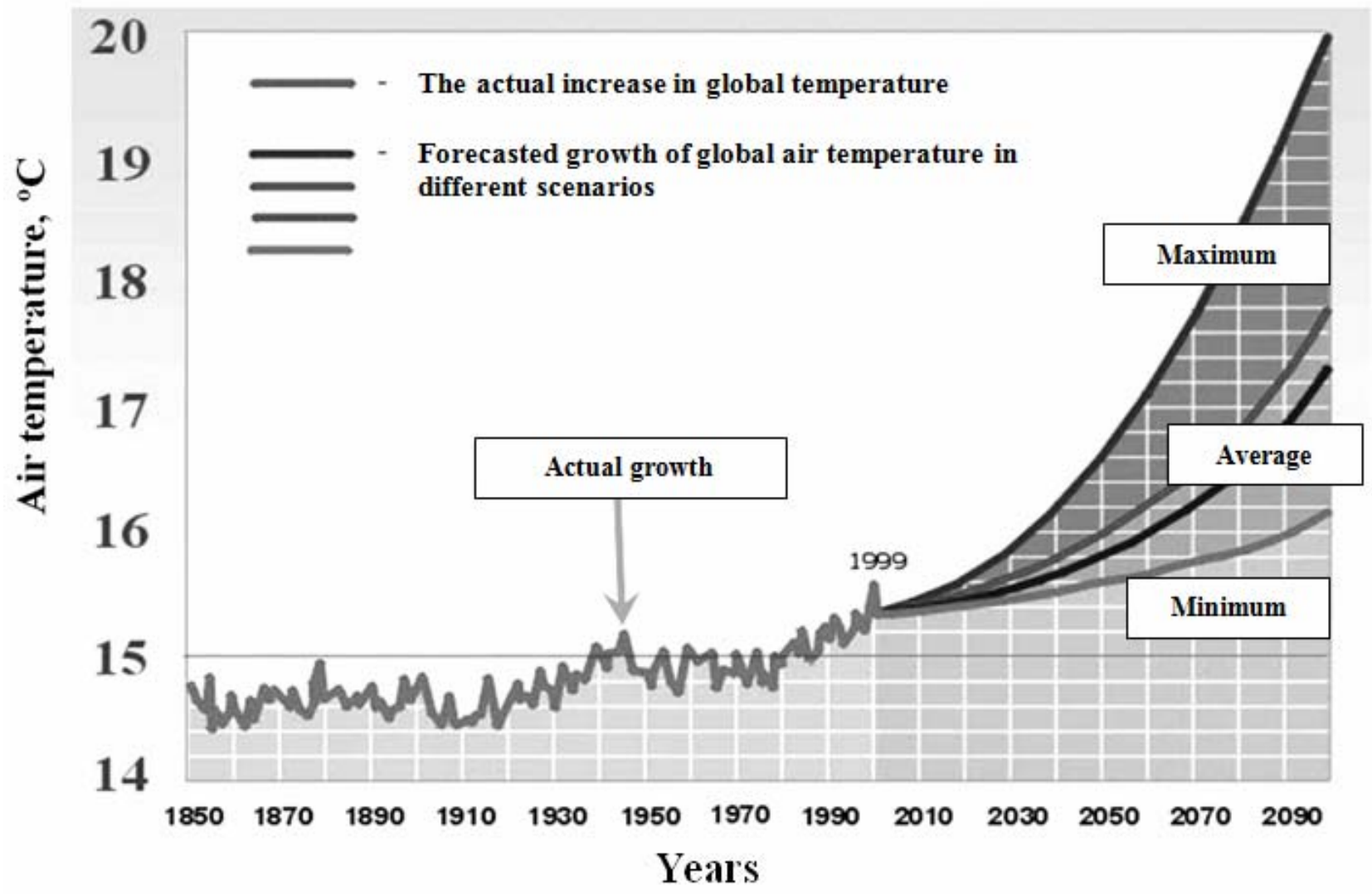

Fig. 1. The actual and predicted temperature regime on Earth for the period from 1850 to 2090 (according to the World Meteorological Organization [5])

Only for the period from 1960 to 2002 in the south of Ukraine was marked 21 years with drought, that means, every second year was dry, and every third was hot-dry. Under such conditions, the effectiveness of irrigation will constantly increase, so the development of irrigated land reclamation should be a priority area of state agricultural policy, especially in the Southern Steppe of Ukraine.

As a priority task on this path, which the scientific team solves at the Institute of Irrigation Farming of the NAAS, is minimizing the land reclamation load, based on the rational water use. In addition, water shortages and an exacerbated environmental situation become new, most important criteria for modern irrigation 
approaches $[9,10]$.

In the natural and climatic sense, the Southern Steppe of Ukraine is characterized by high maintenance of thermal resources, on the background of which in recent years there are climate changes, which in the majority are equated with the phenomena of global warming (Fig. 2).

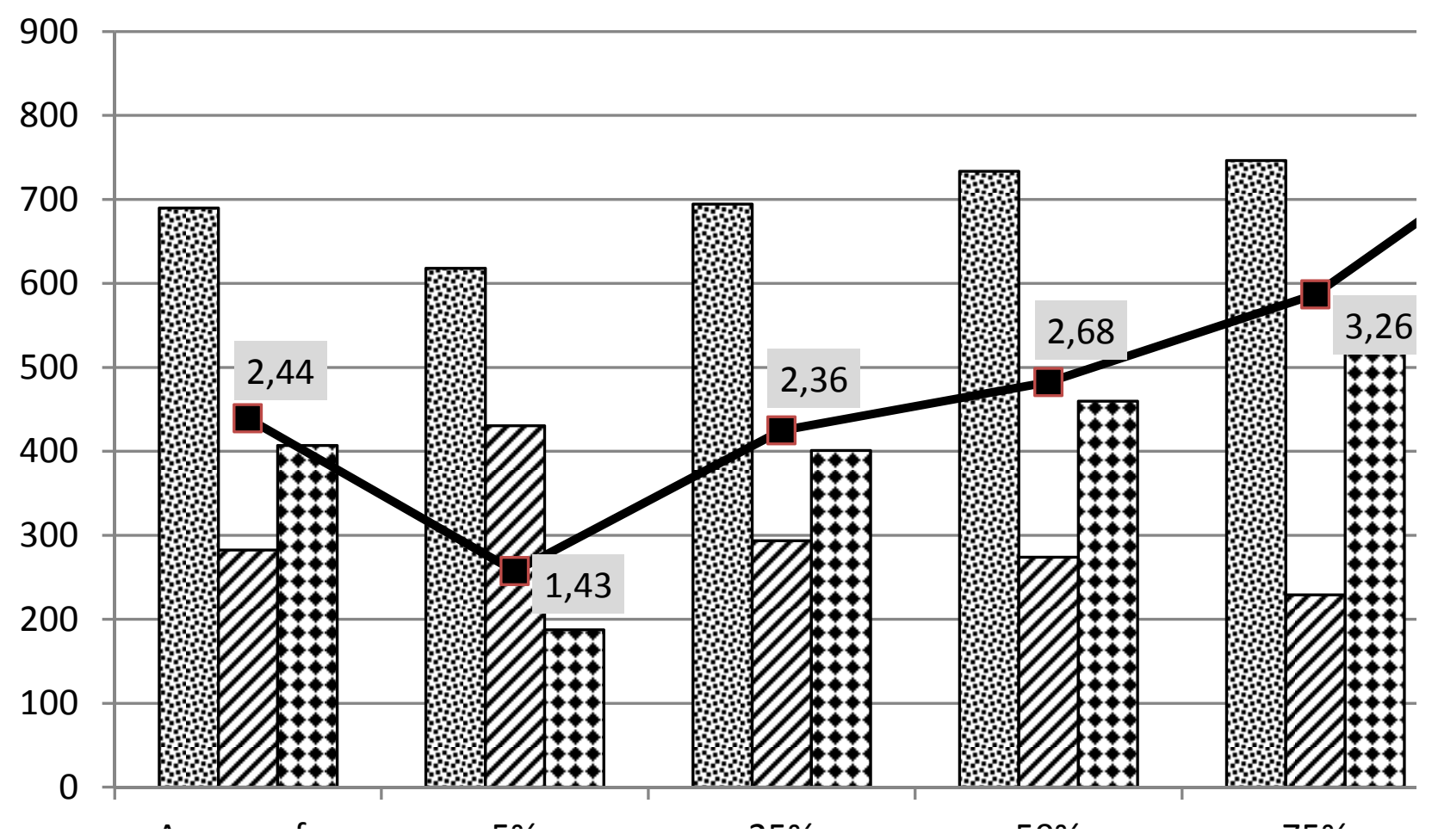

Fig. 2. Elements of water balance and coefficient of aridity depending on the availability of precipitation (according to the agrometeorological station Kherson)

Thus, in recent decades, the average annual air temperature has risen by $1.9{ }^{\circ} \mathrm{C}$, and in the summer months by $3.6-3.9^{\circ} \mathrm{C}$, reaching a maximum daily average of $24.6^{\circ} \mathrm{C}$ in July.

In addition, during the last 35 years there has been a decrease in the amount of rainfall and a violation of their uniform coming during the growing season, which led to a decrease in the aridity coefficient to 1.432.36 in dry and medium dry years.

In addition, the scenarios of temperature rise are based on actual climate change, they take into account the increase in the concentration of greenhouse gases in the atmosphere. It is the greenhouse effect factor that is considered to be a major factor in global warming [11-13]. The hardest scenarios suggest an increase in carbon dioxide in the atmosphere in two or more times over this period. If you take the last 30 years, winter has warmed significantly in Ukraine, January is warmer now, on average $2.5^{\circ} \mathrm{C}$, February $-2{ }^{\circ} \mathrm{C}$, December - remained unchanged [14].

It should be noted that there are a number of negative factors on global warming. Thus, warming can lead to an increase in the harmfulness of thermal stress, a decrease in plant productivity due to low humidity of air and drywall, an increase in the generation of pathogens of many diseases, and so on. [15]. As a result of these factors, agriculture will have to adapt more than other industries. In the south of the country, it is necessary to restore and expand artificial moisture, as Ukraine has enough water to provide irrigation. In the northern and central regions of Ukraine, a set of crops and sow drought-tolerant crops that are characteristic of the Southern Steppe or also arrange irrigation should be reconsidered.

It is projected that by 2030 the volume of emissions of major GHGs without additional efforts will increase by $25-90 \%$ compared with 2000 [16]. Using the right strategy can slow down and stabilize the increase in the amount of greenhouse gas emissions to the atmosphere. By this time, developed countries have announced their targets for reducing emissions by 2020 , but most of these values are far behind the designated IPCC range, which set emission reductions in 2020 at $25-40 \%$ below the 1990 level. It is necessary to limit the 
temperature increase to $2 \mathrm{C}$.

According to the prevailing models, it has been established that climate change is faster than anticipated. Already by 2050, the average annual temperature of the Earth is expected to increase by 2 degrees Celsius [15]. Since 1990, natural disasters (floods, droughts, storms, forest fires) began to occur almost twice as often due to climate change. Also, there are negative trends in climate drought, which in different soil-climatic zones cause lower crop yields. Such factors make it necessary to conduct research on the adaptation of agricultural systems to climate change, in particular the wide introduction and improvement of innovative technologies of artificial humidification.

The Institute of Irrigated Farming belongs to the leading research institutions of the National Academy of Agrarian Sciences of Ukraine. Scientists of the Institute are working on solving scientific and practical problems of agriculture on irrigated and non-irrigated lands. According to the results of the research, intensive and biologized technologies of cultivating crops have been developed, measures have been proposed to solve the urgent problems of increasing the productivity of agricultural production and competitiveness in world markets. In close cooperation with scientists and specialists of the network of research facilities of the Institute, domestic innovative developments aimed at water and resource conservation, increase of economic, energy and ecological efficiency of agriculture of Ukraine were introduced into production.

The result of the scientists of the Institute of Irrigated Farming of the National Academy of Agrarian Sciences is the development and wide introduction into the production of new, adapted to the dry conditions of the Southern Steppe region of Ukraine, agricultural systems, rational and environmentally safe nature management, conservation of soil fertility and the environment; the development of new genetic and biotechnological breeding methods through which more than 70 varieties and hybrids of wheat, corn, soya, alfalfa, perennial grasses, tomatoes, cotton, which are competitive and adapted to the conditions of the southern region and irrigation, have been created. Much of the varieties produced are national standards, which by productivity are $15-30 \%$ higher than the analogues. The Institute and research facilities at the high level organize the work on conducting primary and elite seed production with the further implementation by seeds of high reproductions to agricultural producers from different regions of Ukraine and abroad.

The development of the Institute of Irrigated Farming is a scientific and technical basis for agriculture on irrigated lands in the southern region. In the rotation crop rotations of widespread distribution in the region a system of energy-saving soil cultivation has been developed, which provides savings of fuel and lubricants (by $20 \%$ ), with a decrease in the energy intensity of the process (by $40 \%$ ). Also, the scientifically grounded structure of crop areas on irrigated lands for agricultural enterprises of different specialization has been proved (Table 1).

It has been proved that in order to ensure maximum irrigation productivity in large-scale farms with livestock production, the largest share in crop rotation (40-45\%) is necessary for grain and fodder crops.

In farms specializing in the production of grains and industrial crops, during the formation of crop rotation, an absolute advantage (at the level of 50-60\%) for grain crops, including winter wheat - 20-25 should be given; corn $-20-25 \%$, as well as technical crops, mainly soybeans $-20-25 \%$. In the farms of the vegetable sector, the share of vegetable crops and potatoes should be increased to $50-60 \%$ due to the restriction of areas under cereals and fodder crops. For drip irrigation, the proportion of vegetables and potatoes should be increased to $80 \%$.

Table 1. Scientifically grounded structure of sown areas on irrigated lands for agricultural enterprises of different specialization,\% (according to the Institute of Irrigated Farming, NAAS)

\begin{tabular}{|c|c|c|c|c|}
\hline \multirow[b]{2}{*}{ Crops } & \multirow[b]{2}{*}{$\begin{array}{c}\text { Large-scale farms } \\
\text { with livestock } \\
\text { breeding }\end{array}$} & \multirow[b]{2}{*}{$\begin{array}{l}\text { Facilities for the } \\
\text { production of grain } \\
\text { and technical crops }\end{array}$} & \multicolumn{2}{|c|}{ Vegetable field farms } \\
\hline & & & $\begin{array}{c}\text { normal } \\
\text { irrigation }\end{array}$ & drip irrigation \\
\hline Cereals - all & $40-45$ & $50-60$ & $20-25$ & - \\
\hline incl. winter wheat & $18-20$ & $20-25$ & $20-25$ & - \\
\hline corn & $18-20$ & $20-25$ & - & - \\
\hline Technical - all & $5-10$ & $30-35$ & - & - \\
\hline
\end{tabular}




\begin{tabular}{|l|c|c|c|c|}
\hline incl. soy & $5-10$ & $20-25$ & - & - \\
\hline rape & - & to 5 & - & - \\
\hline sunflower & - & to 5 & - & 80 \\
\hline $\begin{array}{l}\text { Vegetables and } \\
\text { potatoes - all }\end{array}$ & - & - & $50-60$ & 20 \\
\hline Fodder - all & $40-45$ & $10-20$ & $20-25$ & - \\
\hline \begin{tabular}{l} 
incl. perennial grasses \\
\hline
\end{tabular}
\end{tabular}

The main technical and economic indicators of the Institute's scientific developments, taking into account their patent purity, are characterized by a high level of competitiveness in the domestic and foreign agrarian markets, since most of them are better than domestic analogues, and in some cases, such developments have no analogues in Ukraine. The main developments of the Institute of Irrigated Farming include special software and information systems for managing irrigation regimes and rationing of agro-resource costs; new ways of creating a selection material of alfalfa and tomatoes; optimized seed production systems with the development of the newest methods of reproduction of potato material, etc.

At the same time, there are a number of unresolved issues for the innovative development of melioration in the Southern Steppe. In the near future, it is necessary to deepen research aimed at improving the moisture content of agricultural crops through the use of resource-saving cultivation technologies.

\section{Conclusions}

Thus, irrigation in conditions of increasing the dryness of the climate is a decisive measure of intensification of agricultural production in the Steppe zone of Ukraine. Over the past decade, global environmental threats have been exacerbated on the Earth, including climate change, desertification, loss of biodiversity, which destroys natural resources and endangers mankind's existence. In Ukraine, these threats are no less dangerous, especially for climate change, which is manifested by severe drought in the south, and floods in the western regions. In addition, the degradation of soils, which affects not only the yield and quality of crop production, but also causes significant economic losses at the regional and state levels, is an extremely urgent problem. The need for irrigation development is confirmed by the three UN Conventions on Biodiversity Protection, the UN Convention to Combat Desertification, the UN Framework Convention on Climate Change.

To overcome the negative impact of climate change, desertification and soil degradation, which have a significant impact on the efficiency of the functioning of the agrarian sector of the economy, the scientific institutions of the National Academy of Agrarian Sciences of Ukraine have developed highly effective innovative technologies for the production of agricultural products on irrigated lands. At the same time, the change of land relations in Ukraine requires an in-depth theoretical substantiation and production introduction of an intensive agricultural system on irrigated lands in accordance with the specialization of farms on the basis of adaptation to climate change, energy conservation, economic feasibility and environmental safety.

The issue of optimization of irrigation interaction with the structure of crop areas, crop rotations, fertilizer systems, soil cultivation, protection of plants from harmful organisms on the background of complex land reclamation and mechanization of technological processes that promote more full use of the natural and climatic potential of the region, ensuring the implementation of genetically determined productivity potential of the new varieties and hybrids of agricultural crops should be at the center of attention of agrarian science of Ukraine in the near future, special from the point of view of adapting agricultural systems to irrigated lands in the context of global climate change.

\section{Bibliography}

1. Romashchenko M.I., Sobko O.O., Savchuk D.P. et al. (2003). Pro deiaki zavdannia ahrarnoi nauky u zviazku zi zminamy klimatu. Naukova dopovid-informatsiia. [About some problems of agrarian science in connection with climate change. Scientific report-information]. Kyiv. 46 p. [In Ukrainian]. 
2. Vozhehova R.A., Biliaieva I.M. (2016). Aktualni problemy ta perspektyvni napriamy rozvytku zroshennia $v$ Ukraini ta sviti $v$ umovakh zmin klimatu. [Actual problems and perspective directions of irrigation development in Ukraine and the world in conditions of climate change]. Tavriiskyi naukovyi visnyk. Kherson. Vyp. 95. P. 40 - 46. [In Ukrainian].

3. Netis I.T. (1994). Zmina klimatu $v$ zoni zroshennia. [Climate change in the irrigation zone]. Zroshuvane zemlerobstvo. Vyp. 39. P. 7 - 12. [In Ukrainian].

4. Prosunko V. (1999). Vplyv hlobalnykh zmin klimatu na pohodu v Ukraini. [Impact of Global Climate Change on Weather in Ukraine]. Nauka i suspilstvo. No 10 - 12. P. 60 - 63. [In Ukrainian].

5. Dmytrenko V.P. (2001). Fruitfulness of Climate is the Basis of the General Concept of Agrometeorological Adaption Strategies to Climate Variability and Climate Change. Agrometeorology in the 21 st Century Needs and Perspectives: Contributions from Members on Operational Applications in Agrometeorology and from Discussants of the Papers Presented at the International Workshop. Commission for Agricultural Meteorology. CAgM Report No. 77b. WMO/TD No. 1029. Geneva, Switzerland, May 2001. P. $43-45$.

6. Filipenko L.A., Zhovtonoh O.I., Demenkova T.F. (2010). Adaptatsiia planiv vodokorystuvannia do zmin klimatychnykh umov u zoni zroshennia Ukrainy. [Adaptation of water use plans to changes in climatic conditions in the irrigation zone of Ukraine]. Vodne hospodarstvo Ukrainy. No 4. P. 23 - 29. [In Ukrainian].

7. Randall D.A., Wood R.A., Bony S. et al. (2007). Climate Models and Their Evaluation. Climate Change 2007: The Physical Science Basis. Contribution of Working Group I to the Fourth Assessment Report of the Intergovernmental Panel on Climate Change. Cambridge University Press, Cambridge, United Kingdom and New York, NY, USA. P. $589-662$.

8. Sadras V.O., Cassman K.G.G., Grassini P. et al. (2015). Yield gap analysis of field crops. Methods and case studies. FAO Water Reports. Rome, Italy. No 41.82 p.

9. Vozhehova R.A., Kokovikhin S.V., Biliaieva I.M. (2015). Perspektyvy vykorystannia informatsiinykh system dlia ahrometeorolohichnoho zabezpechennia zroshuvanoho zemlerobstva $v$ umovakh pivdnia Ukrainy. [Perspectives of use of information systems for agrometeorological provision of irrigated agriculture in the conditions of southern Ukraine]. Zroshuvane zemlerobstvo: mizhvidomchyi tematychnyi naukovyi zbirnyk. Kherson. Vyp. 64. P. 5 - 8. [In Ukrainian].

10. Vozhehova R.A., Biliaieva I.M., Kokovikhin S.V. (2017). Adaptuvannia system zroshuvanoho zemlerobstva do lokalnykh ta rehionalnykh umov Pivdennoho Stepu Ukrainy ta hlobalnykh zmin klimatu. [Adaptation of Irrigated Farming Systems to Local and Regional Conditions of the Southern Steppe of Ukraine and Global Climate Change]. Tavriiskyi naukovyi visnyk. Kherson. Vyp.98. P. 23 - 28. [In Ukrainian].

11. Asfaw S., Maggio G. (2016). Gender integration into climate-smart agriculture. Tools for data collection and analysis for policy and research. Food and Agriculture Organization of the United Nations Rome, $20 \mathrm{p}$.

12. Graedel T.E., Crutzen P.J. (1995). Atmosphere, Climate and Change. New York. W.H. Freeman, $208 \mathrm{p}$.

13. Konuma H. (2015). Climate-Smart Agriculture: A call for action. FAO. Synthesis of the Asia-Pacific Regional Workshop. Bangkok. Thailand, $120 \mathrm{p}$.

14. Kiriiak Yu.P., Kovalenko A.M., Biliaieva I.M. et al. (2017). Doslidzhennia zmin temperaturnoho rezhymu za bahatorichnyi period u Pivdenno-Stepovii zoni Ukrainy ta vyvchennia yoho vplyvu na produktyvnist pshenytsi ozymoi. [Investigation of temperature regime changes for a long period in the Southern Steppe zone of Ukraine and studying its influence on the productivity of winter wheat.]. Tavriiskyi naukovyi visnyk. Kherson. Vyp. 97. P. 53 - 59. [In Ukrainian].

15. Nicolas H. (2008). The economics of climate change: the Stern review. Great Britain: Treasury. P. $57-61$.

16. Hellegers H.J., Perry C.J. (2004). Water as an economic good in irrigated agriculture: Theory and practice. The Hague, Agricultural Economics Research Institute (LEI), Report 3.04.12. P. 152 - 155. 